\title{
Bricks And Clicks And The Future Of The Academic Library
}

Nancy Levesque, Director, (Email: levesque@cariboo.bc.ca), University College of the Cariboo, Canada

\begin{abstract}
Today's librarians must create an engaging setting for teaching and learning by offering a welcoming library space, a wealth of online resources, combined with librarians' expertise and collaborative instruction programs. Rapid advances in information technologies, new methods of teaching and learning, and the changing makeup of university student populations are impacting the academic library. Working together, librarians and faculty can develop active learning experiences for students, and provide opportunities to integrate resources and discovery.
\end{abstract}

\section{Introduction}

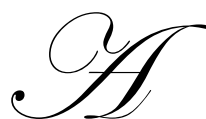

cademic libraries are undergoing a transformation, driven by changes in teaching and learning, new information technologies, and new needs of students. Added pressures of flat or shrinking budgets, the rise in costs of scholarly publications, and greater demands for accountability, challenge university libraries to reflect on their future in a complex and increasingly digital world.

The present may seem bleak for academic libraries and the future daunting, but if the focus is on the learner, if the question is "what do we want to happen in the university library, on/campus and online?" then a sense of direction can be identified and strategies developed to reach the library's vision.

\section{Learning and students}

The goals of the academic library, its programs, collections and services, must align with and support the mission of the university - - to educate students and extend scholarship.

Good learning is relevant, linking theory to practice. It happens best when students are challenged and given a range of interactive experiences, providing them with opportunities for interaction with classmates and teachers. A 1998 joint report of the American Association for Higher Education, "Powerful Partnerships: a shared responsibility for learning"1 advocates for greater cooperation among professionals involved with student learning. Faculty and librarians who partner to design learning pathways, enable students to explore and discover connections between their courses and experiences.

The National (U.S.) Survey of Student Engagement (NSSE) ${ }^{2}$ continually indicates that students learn more when they are actively involved with their studies, challenged to work at problem-solving, and collaborate with others on projects. A two-year study by the Association of American Universities, "Understanding University Success" ${ }^{\prime 3}$ found that students' intellectual behaviours and good study habits gained them academic success. Critical thinking skills, good communication, analysis, problem-solving and the ability to use information technology are all key success factors for university students.

As students learn the subject material and content of their courses, they must, at the same time, learn how to handle information within the discipline. L. McDowell writing in The British Journal of Educational Technology ${ }^{4}$ argues that students need to learn information skills in the context of their studies. This is what we attempt to do at the UCC Library: to show students the relevance of scholarly research materials to their class, their program, their careers. Our library classes are designed to integrate resources and activities into the course 
curriculum. Librarians engage students in class, both to challenge and support them to become independent learners.

\section{Information Technologies and (e)-learning}

Teaching, learning and libraries continue to be shaped by information technologies. The benefits are many: improved access to a greater variety of resources; enhanced communication; interaction; more flexibility; and reduced barriers of place and time. Information technologies are of value when they enable interactive learning and strengthen the social connections among faculty and students; when students have access to a wealth of online resources and experiences.

But the sheer enormity of the Web, and online research databases and e-resources licensed by academic libraries can overwhelm students, even this Google generation! Today's university student is online across campus or across the world, studying and working beyond "normal" hours. It is more important and more difficult to develop programs and services online that match students needs and capabilities.

Chickering and Gamson's 1987 classic study of good practice in undergraduate education ${ }^{5}$ was updated in $1996^{6}$. The authors found most recently that the use of technology in teaching and learning enriches the interaction, access, feedback and support among teacher and students. The California State University, Chico's "Rubric for Online Instruction" contains criteria based on Chickering and Gamson's principles, demonstrating the relevancy of the best practices articulated almost twenty years ago.

It is crucial for faculty and librarians to have guidelines for online learning as more universities offer elearning courses. The challenge of "distance education" is to bring education to students - - all the instruction and support that happen on campus. What takes place in the library and in the classroom must be transferred to an online environment. This can be accomplished when course faculty and librarians work together to develop curriculum and support services that engage students. Care must be taken to be deliberately attentive to the learning needs of students online. E-learning is still learning! and students and faculty must be able to meet (virtually), explore, search, analyze, respond and react. Librarians, faculty and IT staff must monitor student learning to gauge the effectiveness of the technology, course and service design and delivery. Many faculty are using course management software (WebCT, Blackboard, etc.). At UCC, the librarians work with course faculty to embed library resources and links to databases and online subject guides on the class WebCT page.

\section{Information literacy}

The Association of College and Research Libraries (ACRL) has information literacy standards and guidelines that librarians use as models for their programs of library instruction, both on campus and online e $^{8,9,10}$. ACRL guidelines, developed by faculty and librarians, urge academic librarians to design library instruction classes that incorporate active learning, relate to the course of study, and build on the experiences of students.

Students need to be able to analyze their information needs, know how to search, access, evaluate and use appropriate resources. They need practice, support, reinforcement and positive learning experiences as they gather information from a variety of sources. Meeting the information literacy needs of students is best done by integrating library instruction with the course curriculum. This involves collaborative (faculty-librarian) planning, design and teaching to create a learning environment that challenges students to discover and test their own ideas and research findings. Librarians and faculty share common goals for student success; our learning outcomes for students include critical thinking, research, evaluation and communication skills. Mastery of information literacy and information technology skills equips students to become independent life-long learners.

\section{The library as place}

Despite dire warnings of the death of print, academic library building projects have continued in a stable pattern over the past several years. Authors Shill and Tonner in their article, "Creating a Better Place: physical 
improvements in academic libraries 1995-2002", ${ }^{11}$ found that new library buildings were designed to accommodate growing print collections, to provide more study space and to improve access to computers and information technology. Overall post-project satisfaction was high, with increased usage the norm. These new libraries combined the latest information technologies with a variety of study and instruction spaces that demonstrated the library as central to the educational experience of the university.

Yale Librarian Emeritus, Scott Bennett, in his report for the Council on Libraries and Information Resources (CLIR), November $2003^{12}$ observes that campus libraries are building for the future needs of teaching and learning and the shared tasks of faculty, librarians and students. Spaces are designed for change, flexibility, new growth, and developments in technologies.

Libraries are being renovated or built with the users in mind, offering welcoming spaces for quiet and group study, project work, classrooms, labs for multimedia production, and increasingly, an Information or Learning Commons.

\section{Learning Commons}

Changes in teaching and learning combined with advances in information technologies have led to the concept of an Information or more appropriately, a Learning Commons. Faculty, students and librarians rely increasingly on information technology: the array of online databases, full-text journals, e-books, library guides, websites, multimedia software and output production tools. The richness of electronic resources brings a complexity too, resulting in students needing more support to access and use effectively their research findings and data. Students want the library to be a place where they can find print and online information, work individually and in groups using their research, confer with librarians and IT staff, meet with course faculty for feedback and direction, and then prepare and produce their papers, reports, presentations.

The Learning Commons extends and consolidates in one service point the latest information technology hardware and software, with the help desks of librarians and IT professionals. L. MacWhinnie describes the setting in "The Information Commons: the academic library of the future". ${ }^{13}$ An Information or Learning Commons enables active learning, provides timely support and training to students by expert staff, and ample work spaces for collaboration among students, librarians and faculty.

Learning Commons are designated spaces that often have extended hours and can be independently accessed once the rest of the library building is closed. Learning Commons are very popular with students and wellused. Visits to libraries and their Learning Commons at the University of Calgary; University of Toronto; University of Nevada, Las Vegas; University of Southern California, San Diego; University of British Columbia; Coventry University; Tufts University, Boston, all confirm that Information/Learning Commons respond to the learning needs of students. University of Calgary reports increases in library instruction classes, usage of workstations, and group study rooms. ${ }^{14}$ Other sites report high usage as well.

A Learning Commons brings the users together with each other, with technologies, and with support personnel, all within the larger context and setting of the library's collections and services. Knowledgeable staff are the key component of a Learning Commons; they help students make sense of the information found online and in print. Active learning is fostered and enabled, guided by librarians teaching students critical thinking and analysis as they research and work on their assignments. Information/Learning Commons are important features in today's academic library. They enable the librarians, faculty and IT staff to support the mission of the university to enrich student learning. Librarians will need to monitor and assess their Learning Commons and develop measures to gauge the effectiveness of this multi-faceted service area.

\section{UCC}

UCC is in a pivotal stage in its history. It was founded as Cariboo College in 1971 as a two-year community college serving Kamloops, British Columbia, and region in the south central interior of the province. In 
1989 the province of British Columbia granted Cariboo College degree-granting status, and the new University College of the Cariboo began offering undergraduate (bachelors) degrees. Today there are twelve degree programs with a range of majors, in addition to career/technical/vocational programs that ladder into the degrees, serving $9000+$ students.

On March 19, 2004 the Premier of British Columbia announced in Kamloops that effective April 1, 2005, UCC would become Canada's newest university and would as well, incorporate B.C.'s Open University into the yetto-be-named, new institution. ${ }^{15}$ Capital funding was also committed for the construction of a new library building.

This is tremendous news for UCC! Our comprehensiveness and regional focus are maintained. New legislation and a new university name will be conferred within a year. The expertise of BCOU's online learning will be combined with current program strengths on UCC campuses. For the Library, the challenge is to balance the online and onsite needs of users. The addition of the BC Open University's technology, online programs and services, plus a new larger library building, presents UCC/new University with unique opportunities. How will we shape our future? What do we want to happen in our library?

\section{Notes for the future}

Our aim is to promote learning, study, teaching, research; to create library spaces and services that focus on the activities of the university community. The Keystone Principles, developed in 1999 by a group of university librarians, affirms the academic library as an "intellectual crossroad, the hub of the knowledge network". ${ }^{16}$ Indeed, the academic library's future is a networked one, depending on collaboration with faculty, IT professionals, and with other libraries and consortia. The rich tradition of academic libraries to collect, preserve and disseminate the research of scholars continues in print resources and expands now to a digital realm.

\section{Digital collaboration}

The need remains for academic libraries to manage and balance collections in all formats. The sheer mass of published information, the costs of licensing research databases, and the related infrastructure needs have brought libraries together in consortia with goals to maximize resources and contain expenditures. Canadian academic libraries have formed various consortia, often based on geographic regions, to share resources and to license access to online databases. The UCC library belongs to the provincial (British Columbia) Electronic Library Network, ${ }^{17}$ and the western (Canada) Council of Prairie and Pacific University Libraries (COPPUL). ${ }^{18}$

In 1999, 64 Canadian universities and their libraries collaborated on a $\$ 50$ million project to license access to 750 science and medical journals. ${ }^{19}$ Funding came from the federal and provincial governments and the universities. The project was welcomed by researchers and their libraries across the country. A new phase of the project is now underway to extend the scope of online resources licensed and to include new member libraries.

Academic libraries are spending more of their budgets on e-resources, often at the expense of print journals and monographs. Even so, the online environment is not complete or consistent. There are differences in access, full-text coverage, indexing, archiving, platforms, and copyright. The research environment is dynamic, changing and costly with much at stake for universities, faculty and publishers. Librarians and faculty are challenged to preserve, protect and promote scholarly communication. This is not just a library issue.

There are a growing number of alternatives to the commercial for-profit scholarly publishers: Bio Med Central in the U.K. ${ }^{20}$ and Project Euclid in the U.S. ${ }^{21}$ are two examples. Sherpa ${ }^{22}$ (Securing a Hybrid Environment for Research Preservation and Access) offers scholars direct access to research available in open access archives.

Clifford Lynch outlines the importance of institutional repositories to capture the intellectual scholarship of universities and make it available to researchers. ${ }^{23}$ MIT's DSpace ${ }^{24}$ is a model for the development of institutional repositories, as is $\mathrm{TWiki}^{25}$, which uses an open-source web-based tool that allows faculty to add, edit, link and 
search web-pages. These new, more "open" models of scholarly communication depend on the collaboration and mutual support of campus faculty, librarians and IT staff as universities evolve (back) into publishing activities.

\section{A library for tomorrow}

Clearly rapid changes in information technologies are affecting the university library's collections, services and spaces. There is a continued and growing need for more online resources, and services. Virtual reference (real time) services bring immediate instruction and support to students. University libraries are reaching across time zones to ensure round-the-clock coverage and service. E-reserves, e-books, videos and multi-media on streaming software, open source digital collections with network connections - - these are all services required to support teaching, learning and research online and onsite.

Our (new) libraries must include the latest in information technology, wireless access, production and multimedia software and work stations for users, with these now combined with the expertise of librarians and IT staff help desks, often focused in a Learning Commons area. As well, print collections of books, journals, government reports, special collections and archives are essential resources to access the past and present.

The key element, the critical success factor for the academic library of the $21^{\text {st }}$ century, is to be a teaching library. The university requires the library to serve as a place for scholars and students to gather, discover, research and collaborate. Librarians contribute to the university's mission by participating in the educational experiences of teaching, learning and research. The academic library is a centre for the richness of scholarship, print and electronic, and the opportunities for exploration, discovery and sharing among librarians, faculty and students.

Information literacy is an integral part of the educational success of students. Librarians and faculty must involve students in planning and shaping their learning, helping them to gain confidence and develop a fluency in handling information. The American Association for Higher Education's (AAHE) report, "Student Learning and Leadership" 26 urges universities to involve students in developing the university's educational programs. The energy, initiative and experience of students can be a guide and asset for future directions. In the end, what matters most is not the library building or the technology, but how they are used to support the mission and vision of the university. It is the partnerships, the synergies among faculty, librarians and students sharing their knowledge that is important. This interaction and collaboration is the value and the future of the academic library as it becomes a learning library.

\section{Notes}

\footnotetext{
${ }^{1}$ American Association for Higher Education, American College Personnel Association, National Association of Student Personnel Administrators, Powerful Partnerships: A Shared Responsibility for Learning. A Joint Report (June 1998). Available: http://aahe.org/assessment/joint.htm [May 7, 2004]

${ }^{2}$ Indiana University Centre for Post Secondary Research, Policy and Planning, National Survey of Student Engagement: the College Student Report (2003). Available: http://www.iub.edu/ nsse [May 7, 2004] ${ }^{3}$ Association of American Universities and The Pew Charitable Trusts, Understanding University Success (April 2003). Available: http://pewtrusts.com/ideas/ideas_item.cfm?content_item_id=1566\&content type_id=8 [May 7, 2004]

${ }^{4}$ Liz McDowell, "Electronic information resources in undergraduate education: an exploratory study of opportunities for student learning and independence," British Journal of Educational Technology 33,3 (2002): 255-266.

${ }^{5}$ A.W. Chickering and Z.F. Gamson, "Seven principles for good practice in undergraduate education," AAHE Bulletin 39 (1987): 3-7.

${ }^{6}$ A.W. Chickering and S.C. Ehrmann, "Implementing the seven principles: technology as lever," AAHE Bulletin 49 (1996): 3-6.

7 California State University, Chico, Rubric for Online Instruction (2002). Available: http://www.csuchico.edu/celt/roi/ [May 11, 2004]
} 
${ }^{8}$ Association of College and Research Libraries, Information Literacy Competency Standards for Higher Education (January 2000). Available: http://www.ala.org/ala/acrl/acrlstandards/informationliteracycompetency.htm [May 7, 2004]

${ }_{9}$, Objectives for Information Literacy Instruction: a Model Statement for Academic Librarians (January 2001). Available: http://www.ala.org/ala/acrl/acrlstandards/objectivesinformation.htm [May 7,2004]

${ }_{10}$, Characteristics of Programs of Information Literacy that Illustrate Best Practices: A Guideline (June 2003). Available: http://www.ala.org/ala/acrl/acrlstandards/characteristics.htm [May 7, 2004]

${ }^{11}$ Harold B. Shill and Shaun Tonner, "Creating a Better Place: Physical Improvements in Academic Libraries, 1995-2002", College of Research Libraries 64,6 (November 2003): 431-466.

${ }^{12}$ Scott Bennett, Libraries Designed for Learning (Council on Library and Information Resources, November 2003). Available: http://www.clir.org/pubs/reports/pub122/contents.html [May 7, 2004]

${ }^{13}$ Laurie A. MacWhinnie, "The Information Commons: The Academic Library of the Future," portal: Libraries and the Academy, 3,2 (2003): 241-257.

${ }^{14}$ University of Calgary, Information Commons Fact Sheet. Available: http://www.ucalgary.ca/informationcommons/facts.html [May 7, 2004]

${ }^{15}$ Office of the Premier, Ministry of Advanced Education, "News Release", (March 19, 2004): 1-2. Available: http://www2.news.gov.bc.ca/nrm news_releases/2004MAE0008-000175.htm [May 7, 2004]

${ }^{16}$ Carla Stoffle and others, “The Keystone Principles", ARL Bimonthly Report 207 (1999): 1-4. Available: http://www.arl.org/newsltr/207/keystone.html [May 7, 2004]

17 Electronic Library Network. Available: http://www.eln.bc.ca/ [May 7, 2004]

${ }^{18}$ Council of Prairie and Pacific University Libraries. Available: http:www.coppul.ca/index.html [May 7, 2004]

${ }^{19}$ Canadian National Site Licensing Project. Available: http://www.cnslp.ca/index.php [May 7, 2004]

${ }^{20}$ BioMed Central. Available: http://www.biomedcentral.com// [May 7, 2004]

${ }^{21}$ Project Euclid. Available: http://projecteuclid.org/Dienst/UI/1.0/Home [May 7, 2004]

${ }^{22}$ SHERPA: Securing a Hybrid Environment for Research Preservation and Access. Available: http://www.sherpa.ac.uk//May 7, 2004]

${ }^{23}$ Clifford Lynch, "Institutional Repositories: Essential Infrastructure for Scholarship in the Digital Age", ARL

Bimonthly Report, no. 226 (February 2003): 1-7. Available: http://www.arl.org/newsltr/226/ir.html [May 7, 2004]

${ }_{24}^{24}$ DSpace Federation. http://www.dspace.org/ [May 7, 2004]

${ }^{25}$ TWiki. Available: http://www.twiki.org/ [May 7, 2004]

${ }^{26}$ American Association for Higher Education, "Student Learning and Leadership", New Directions, no. 5 (2003): 1-

2. Available: http://www.aahe.org/specialreports/part5.htm [May 7, 2004] 